\title{
Michèle Clément-Guillaume De Sauza, Qui déplore la mort de Marot?
}

\section{Filippo Fassina}

\section{Q OpenEdition}

1 Journals

\section{Edizione digitale}

URL: https://journals.openedition.org/studifrancesi/4632

DOI: $10.4000 /$ studifrancesi.4632

ISSN: 2421-5856

\section{Editore}

Rosenberg \& Sellier

\section{Edizione cartacea}

Data di pubblicazione: 1 avril 2012

Paginazione: 132

ISSN: 0039-2944

\section{Notizia bibliografica digitale}

Filippo Fassina, «Michèle Clément-Guillaume De Sauza, Qui déplore la mort de Marot?», Studi Francesi [Online], 166 (I | LVI) | 2012, online dal 30 novembre 2015, consultato il 19 novembre 2021. URL: http:// journals.openedition.org/studifrancesi/4632 ; DOI: https://doi.org/10.4000/studifrancesi.4632

Questo documento è stato generato automaticamente il 19 novembre 2021.

\section{(c) (i) (9)}

Studi Francesi è distribuita con Licenza Creative Commons Attribuzione - Non commerciale - Non opere derivate 4.0 Internazionale. 


\title{
Michèle Clément-Guillaume De Sauza, Qui déplore la mort de Marot?
}

\author{
Filippo Fassina
}

\section{NOTIZIA}

MICHÈLE CLÉMENT-GUILLAUME DE SAUZA, Qui déplore la mort de Marot?, «Bibliothèque d'Humanisme et Renaissance», LXXII, 2 (2010), pp. 301-335.

1 Le ultime pagine dell'opera La Description poétique de l'histoire du beau Narcisse (1544) sono, di fatto, un testo autonomo dal titolo Deploration de France sur la mort de Clement Marot son souverain poète. Di questo testo esistono tre edizioni contemporanee: una edita a Parigi da Jehan André, una edita a Rouen da Jehan Lhomme e una edita a Lione da Jean De Tournes. Delle tre edizioni viene fornita una descrizione dettagliata sia dal punto di vista paleografico, sia dal punto di vista filologico, evidenziandone le varianti ortografiche e contenutistiche. Di queste versioni si cerca anche di fornire una cronologia per definire l'archetipo; inoltre, vengono fornite alcune informazioni volte a ricostruire la figura dell'autore di questa Deploration. Infine, viene trattata un'ulteriore déploration, la Complaincte sur la mort de Clement Marot (probabilmente del 1545) di Guillaume des Autels, che permette un'interessante comparazione con il testo anonimo del 1544 . 